\title{
(Con)figuring gender in Bible translation: Cultural, translational and gender critical intersections
}

\begin{abstract}
Author:
Jeremy Punt ${ }^{1}$

\section{Affiliation:}

${ }^{1}$ Faculty of Theology,

University of Stellenbosch,

South Africa

Note:

This article is an edited version of a paper read at the 2013 Nida School of Translation Studies, Misano, Italy, 20-31 May 2013. I wish to express my gratitude and appreciation for the invitation and the opportunity for focused discussion in a stimulating academic and otherwise well-resourced setting.
\end{abstract}

\section{Correspondence to:}

Jeremy Punt

Email:

jpunt@sun.ac.za

Postal address:

Private Bag X1, Matieland

7602 , South Africa

Dates:

Received: 21 Aug. 2013

Accepted: 08 Feb. 2014

Published: 12 June 2014

How to cite this article: Punt, J., 2014, '(Con)figuring gender in Bible translation: Cultural, translational and gender critical intersections', HTS Teologiese Studies/ Theological Studies 70(1), Art. \#2051, 10 pages. http:// dx.doi.org/10.4102/hts. v70i1.2051

\section{Copyright:}

(C) 2014. The Authors. Licensee: AOSIS OpenJournals. This work is licensed under the Creative Commons Attribution License.

\section{Read online:}

The gendered intersection of cultural studies and Bible translation is under acknowledged. Accounting for gender criticism in translation work requires, besides responsible theory and practice of translation, also attention to interwoven gender critical aspects. After a brief investigation of the intersections between biblical, translation and gender studies, translation in a few Pauline texts with bearing on gender and sexuality are investigated.

\section{Introduction}

Translation studies are caught up in a culture war raging in and beyond classical studies, a confrontation which mostly manifests in epistemology and theory. Those called literary theorists hold that the world is constructed of words and that truth is elusive. They are sceptical about science, and therefore see culture as independent of non-cultural forces. For so-called social scientists, however, the world is composed of physical elements, which they explore through models derived from economics, political science and demography. The two positions do not seem to share any common ground. Literary theorists condemn social scientific lists and rubrics of information and their attempts to account for real life through numbers and generalisations, and suspect political bias as mainstay of social scientific work of the scientific enterprise as a whole. Social scientists on their part deride literary theorists' perplexity regarding the rich diversity of human life, and the postmodern impulse to reject and relegate science, facts and truth to 'scarequote status'. A third group, the historical positivists have been around for longer and in their very specific focus on particularities from surviving fragmentary evidence, continue to privilege authorial intent and frown upon both literary and social-science theory (Doran 2012).

One should admit of course to the stereotyped and simplistic nature of such categories, which can be further differentiated and added to. ${ }^{1}$ But what such configurations demonstrate are crucial dividing lines to consider when engaging ancient texts, whether in interpretation, translation, or other investigations. Literary, social, historical and other configurations are committed to the quest for scholarly excellence, the promotion of (their) academic ideals and even the pursuit of intellectual converts. There is little indication that differences will be resolved and no synthesis is anticipated. These culture wars have no peace, truce or even diminished hostilities in sight. What follows will take these theoretical positions as starting point for illustrating the relevance of cultural studies for translation studies amidst the culture wars. In fact, it is on such uneven and contested terrain of theory that one needs to plot, trace and evaluate translation studies, which means neither to take sides nor to insist on facile conjunctures. Methodological - not to mention epistemological - accord in translation theory and work is acknowledged as a distant dream. Scholars increasingly admit that translation and interpretation cannot be separated from one another and that neither of these pursuits can be considered outside of culture and ideology (cf. Elliott \& Boer 2012:2). ${ }^{2}$ Or to put it differently, translation studies (also) are simultaneously impacting on and being impacted upon by contested and contesting theoretical positions and practices serving vested interests (of power). In this vein my contribution is an ideologicalcritical investigation of the intersection of translation and cultural studies, from a gender-critical perspective, with a further purpose to demonstrate how gender is (con)figured in New Testament translations. ${ }^{3}$ Initial brief theoretical considerations are followed by an investigation of the interplay between gender, sexuality and translation issues in a few biblical (Pauline) texts.

1.For more elaborate discussions of theories of interpretation, see for example, Bernstein (1983); Culture Collective (1995); and, Lundin (1993). Some scholars find the use of 'culture wars' ubiquitous to the extent of losing explanatory power, or even contest the culture war thesis in favour of social groups distinctions (e.g. Evans 1997:371-404).

2.Other issues relevant to the cultural and translation studies intersection, for example, culture as translation; translation as boundary crossing; and, translational practices broadly (beyond interlingual practices) conceived, cannot be addressed here.

3.Ideology criticism is not limited to attempts at addressing the biased nature of texts and interpretations, but also challenges the notion of 'fixed meaning' and 'correct interpretation' as, for example, Aichele (2001:61-83) suggests. Ideology refers 'to the ways in which meanings serve in particular circumstances, to establish and sustain relations of power which are systematically asymmetrical' (Thompson 1990:7). Our ideological focus here is on exploring how sex and gender is constructed in translations of the Pauline documents, rather than on their construction in these documents themselves, that is, how certain ideologies have become normalised (Pérez 2003:5); and whilst not denying that ideology often is interwoven into theology and various other spheres, our attention will remain on the translation, culture and gender intersections. A plea such as Werner's for an ethical code in translation (Werner 2012) falls outside our scope. 


\section{Cultural studies and translation work}

The recent work on the role of Bible translations in colonial settings, on missionaries and their goals and on indigenous people and Bible reception as well as the considerable developments that took place since the days of vociferous debates on literal or formal versus dynamic or functional equivalence, all feed into my argument. ${ }^{4}$ On the margins of biblical studies, we have seen work of scholars and theorists such as Nord, Gutt and others making important inroads in translation work. ${ }^{5}$ To take one example pertinent to my argument, the functionalist translation model of Christiane Nord has been mooted as part of a 'cultural turn' in translation studies. ${ }^{6}$

Nord's work moves away from rigid guidelines for establishing equivalence at several linguistic levels between source and target texts, as she opts for descriptive oriented investigations into culture-embedded translational acts. Some cracks start to show however when Nord's (2005) focus on a translation's skopos, that is, the target text's purpose or the pragmatic content of the translator initiator's instructions, is interrupted by her claims regarding the importance of source text analysis. ${ }^{7}$ Serious consideration of the cultural and translation studies intersection appears to require a still broader cultural scope, moving beyond the study of translation's 'function-in-culture' (ibid:24). In fact, whilst her text analysis appears culturally attuned, ${ }^{8}$ at times it amounts to an application of prevailing norms. The alignment of norms of 'our culture' (ibid:32, 73) or 'our culture-specific concept' (ibid:73) with 'average Western cultures' (ibid:201) shows the dominance of and preference for a specific 'culture', and accompanying ideological concerns. Also, her aversion to subjectivity and indeterminism is supported by her insistence on control in translation, which is effected, theoretically at least, through her dominating skopos-theory. ${ }^{9}$ In short, Nord's work interacts with cultural concerns probably more

4.Recent work on colonialism, missionaries and Bible translation includes for example, Boer (2008); Dube (2001), Petterson (2012), Stine (1992). Cf. Punt (2002 2004) for the South(ern) African context. Cf. Porter (2009:117-145; cf. Bailey \& Pippin 1996:1-4) for a recent take on the literal(ist) or formal versus the dynamic or Pippin 1996:1-4) for a recent take on the literal(ist) or formal versus the dynamic or
functional distinction, and for apprehension about the contribution of ideological functional distinction, and for apprehension about the
awareness to translation practice, if not also to theory.

5.Closer to home, the translation project of the new direct Afrikaans Bible translation in South Africa (SA) is largely built on the theories of Christiane Nord (especially her functionalist approach) and Ernst-August Gutt (with his focus on relevance) (cf. Van der Merwe 2012) - space does not allow extensive discussion of these theorists or their work.

6.Nord is selected from many translation theories and theorists, because of our focus on the translation and cultural studies-intersection and given the current attention for Nord's work in South Africa (e.g. through the preparation of the new Afrikaans Bible; cf. Van der Merwe 2012:3).

7.The importance of source-text claims is underwritten by Nord's (2005:32) insistence on 'compatibility between source-text intention and target-text functions if translation is to be possible at all'; that 'the translator must not act contrary to the sender's intention' (ibid:54); and that the translation skopos requires 'equivalence of effect' (ibid:201).

8. For example, 'the meaning or function of a text is not something inherent in the linguistic signs; it cannot simply be extracted by anyone who knows the code. A text is made meaningful by its receiver and for its receiver' (Nord 2001:152).

9.Since this is not primarily or in essence a discussion of Nord's work, two final comments must suffice: one, Nord's use of auctorial intention both with reference to source texts and translations does not sit well with either more functionalist or more subjo or more subjectivist approaches; two, her use of categories such as 'space', 'time', 'culture', and 'text functions' (e.g. Nord 2005:43-83) may create th untenable situation of four disjointed, categorically separate spheres (her claims about the interdependence of extra-textual factors do not resolve the problem of disjointedness altogether, (cf. Nord 2005:83-87). Cf. also the critical review of Nord's 1991 publication by Pym (1993:184-190). than earlier translation studies, but the question is whether it introduces a cultural turn or rather a refined functionalist position?

\section{On cultural and other turns}

Turn-talk in scholarly discourse follows on the heels of the late 20th century linguistic turn, and is part of the scholarly culture wars. The linguistic turn marked the beginning of a new consciousness about hermeneutics and even epistemology in New Testament studies and introduced new practices. Traditional, long-held beliefs in historical objectivity and the ability to describe a past as it actually happened were replaced with the acknowledgement that the past does not exist outside its literary presentation..$^{10}$ As culturally sensitive elements were picked up and translated into biblical studies practices, the notion of a cultural turn (also) became more popular. Literary texts increasingly were seen as part of a larger 'inseparable, relational web of residues and artifacts that hang together in ways that are not always easily comprehensible' (Lopez 2011:80). Such interconnectedness is seen as embedded further in various power constellations and gives rise to claims about a 'political turn' (Stanley 2011:111) in New Testament studies.

With lingering linguistic and incipient political turns, and a growing interest in cultural studies amongst scholars, a 'cultural turn' is discernable in biblical studies. ${ }^{11}$ For some the cultural turn may imply the employment of various poststructural methods to show how language shaped the socio-cultural setting of the early Christian world. For others it may entail the use of cultural anthropology as analytical method. What in any case has become clear is the implication of scholarly movement beyond the universalisms of the Enlightenment and 19th and 20th century liberalism. The result is that scholars more and more have come to view human beings as historical creatures located within the complex matrices of particular cultures and social worlds', and increasingly deal with the 'located, particular, pluralistic, and thoroughly historical nature of human existence, experience, and knowledge' (Davaney 2001:5). In fact, since the latter part of the 20th century, social history is replacing institutional or intellectual history (Martin 2005:4), and investigations are shifting towards the ways in which the socio-cultural settings of antiquity influenced rhetorical strategies found in the ancient texts.

\section{Cultural and biblical studies}

When culture is understood as 'the dynamic and contentious process by which meaning, and with it, power is produced, circulated, and negotiated by all who reside within a particular cultural milieu' (Davaney 2001:5), it follows that cultural studies can be described as an interdisciplinary 'theoretical-political project'. Culture is not a synonym for

10.With the acknowledgement that the past exists only in its literary representation came the realisation that such representations are always imbued with ideologies.

11.The originating moments and location of cultural studies are commonly disputed, yet broadly connected to movements as early as the 1950 s to study also popula or mass culture (Easthope 1994:176) yet variously described (Vanhoozer, Anderson \& Sleasman 2007:248). 
ideology, not even in the Mannheim sense of ideology as more or less a worldview. But the overlaps between culture and ideology are quite evident: ideology is more connected to normalised frameworks of thought, whilst culture refers to learnt behaviour patterns (cf. Pérez 2003:5-6). Cultural studies incorporates these sentiments. Cultural studies has academic and political dimensions that holds to the democratisation of culture and is interested in all cultural productions such as cultural practices, operations, and formations:

At its best, the movement deploys a convergence of research methodologies (not a single or unified methodological prism) to interrogate the valorization of culture, to demystify the politics of representation, to foster practices of self-reflexive inquiry, and to promote actively a radical progressive cultural politics. (Smith 2012) $)^{12}$

In biblical scholarship the once lauded ideals of objectivity and neutrality are increasingly recognised as impossible to achieve, and also berated for obscuring cultural imperialism and ideology. The modernist theory of an ideal observer and narrator is being replaced by the alternative, postmodernist construct of a narrator and observer who is always situated and engaged (Segovia 2000:175). ${ }^{13}$ As much as the Genesis story about the tower of Babel concerns the inevitable need for translation, in a powerful way it also presents the collapse of empire in the sense of showing the impossibility of attaining the complete, the ultimate and the total. It is Babel that shows how every reading is a rewriting, every reading is a translation - it upsets the notion of the original by pointing out its lack, and its constant desire to be translated (Derrida 2002:104-111). Moving away from understanding translation as the objective rendering of an original, and viewing translation rather as crafting an intertextual co-text, requires sensitivity for and concern about the situated persons and positions of translators.

Proceeding from a cultural studies' position is not without danger, particularly in idiosyncratic or even exotic garb. However, a normalising approach is equally dangerous. Describing cultural hermeneutics as 'approaches to interpretation in which the social and cultural location of the interpreter (e.g. feminist, African American) serves as a principle of interpretation' (Vanhoozer et al. 2007:248) does not show self-awareness about the discrepancy it introduces. Quite simply, interpretation is never devoid of social or cultural influence, regardless of the extent of its acknowledgement. Interpretation is in and of itself social and cultural. Interpretation, like translation, can never be aloof of interpreters and is mostly not without consuming

12.This is a worthwhile description of cultural studies which like the term culture also suffers from a wide range of definitions. At the same time, using this understanding of cultural studies is of course not meant to deny other, divergent notions and certainly not to conceive of cultural studies as homogenous.

13.The reigning master paradigm of interpretive neutrality and hermeneutic objectivity is 'a historical experience and cultural reality as particularized and contextualized as any other is bracketed and universalized as normative human experience and reality - the reality and experience of center - with the rest unable to transcend their social locations - the realities and experiences of the margins' to transcend their social locations - the realities and experiences of the margins'
(Segovia 2000:173). Translation work can feed into such a paradigm, as Aichele (Segovia 2000:173). Translation work can feed into such a paradigm, as Aichele
argues: 'Christian sacrifice of the physical text of the scriptures has had important argues: 'Christian sacrifice of the physical text of the scriptures has had important
repercussions for Christian attitudes towards Jews, Muslims, and those of other religions and belief systems, including atheists, for according to the Christian religions and belief systems, including atheists, for according to the Christian
ideology of the canon, the Bible must be brimming with clear, coherent meaning' ideology of the can
(Aichele 2001:83). listeners. Of course, in both instances (even if in various ways) interpreters as well as users of the interpretation simultaneously are connected to and constitutive of their social locations. ${ }^{14}$ In short, no methodological prisms - neither in biblical interpretation nor in Bible translation - are free from wider cultural currents, as all methods are 'culturally contextualized' (Segovia 2008:24).

\section{Cultural studies, biblical studies and translation}

Whilst the cultural turn in biblical studies can be explained variously, the understanding and emphasis upon certain antecedents - unsurprisingly - also are likely to vary between social locations. In biblical studies, it is on the one hand the impending demise of the once all-vanquishing historical critical approach that raises questions about various aspects of biblical studies work. At the same time, increased attention is given to the nature of historical work, ${ }^{15}$ to linguistic and textual concerns and to readers and their interpretative communities and histories. On the other hand, the rise of a more culturally or socially attuned historiography and consideration for the social location of scholars and scholarship begs the question about the modes of including historical consciousness in scholarship, taking social embeddedness of biblical studies as point of departure and frame of understanding. ${ }^{16}$

This starting point implies a rejection of a logocentric approach to translation work, which in simple terms assumes the placement of retrievable meaning in a text by an author. And beyond logocentrism the distinction between textual means and semantic message is no longer evident or useful. ${ }^{17}$ The interpretative interests at play in translation as much as in hermeneutics are now also more in focus, interests which can fruitfully be explored through ideological criticism. In a cultural studies approach both the value and authenticity of popular readings are acknowledged, but without necessarily assuming the legitimacy or condoning the effects of any particular reading. Popular translations and interpretations can be 'an uneven mix of insights, prejudices, contradictions, and images imposed by hegemonic discourse' (Glancy 1998:476), and are not necessarily innovative and liberatory. ${ }^{18}$

14. "The people" are not just passive consumers of meaning, values, and practices devised by the powerful. They are the producers of culture on multiple levels, including through resistance to elites' (Davaney 2001:6).

15.In cultural studies, 'the goal of the historian becomes not the conscious or even unconscious intentions of the author, but the larger matrix of symbol systems provided by the author's society from which he must have drawn whatever resources he used to "speak his mind"' (Martin 2005:17)

16.Cultural studies do not seek to exclude, or take scholarly terrain hostage, as it 'seeks to integrate, in different ways, the historical, formalist, and socio-cultural questions and concerns of other paradigms', but it does seek to do so 'on a different key, with a situated and interested reader and interpreter always at its core' (Segovia 2000:30,41). And translation is always closely connected to ideology: "' $A$. $A$ ny $2000: 30,41)$. And translation is always closely connected to ideology: " $A]$ ny
translation is ideological since the choice of a source texts and the use to which the translation is ideological since the choice of a source texts and the use to which the
subsequent source texts is put is determined by the interests, aims, and objectives of social agents. But ideological elements can also be determined within a text itself' (Schäffner 2003:23)

17.Aichele (2001:61-62) blames both the 'Christian confidence in the reliability of translation' and 'Christian willingness to resolve or overlook the dilemma of a double canon' on a logocentric or 'Greek' approach to language, which separates thought and language. 'The signifier is simply a dispensable transmitting tolerate diversity', and 'in freeing the meaning of the canonical texts from their physical embodiments and allowing the unlimited translation of the scriptures, physical embodiments and allowing the unlimited translation of the scriptures,
Christianity set itself on that course of intolerance and even fanaticism from which it has not yet freed itself' (Aichele 2001:82-83).

18.In fact, scholarly readings can serve a useful purpose in conjunction with popula readings, for example in addressing the needs of the poor (cf. Rowland 1993:239, 241). 
Ideological concerns are not the preserve of the publicly powerful only!

Moreover, ideological concerns characterise 'turn-talk'. It has been suggested that the combination of rhetorical emphasis and feminist theory will enable the 'full-turn' of biblical studies (Schüssler Fiorenza 1999:13). And that a paradigm shift in biblical studies has so far stayed out due to the inability of rhetoric to link up with feminist, liberationist and postcolonial studies. But what would an identity politicsfocused approach such as feminism entail? From a cultural studies perspective identity politics is defined by the Free Dictionary (2014) as 'political attitudes or positions that focus on the concerns of social groups identified mainly on the basis of gender, race, ethnicity, or sexual orientation', ${ }^{19}$ and conjure up concern about the imposition of another regulating regime with which to replace the former. Without suggesting some impossible neutrality in interpretation and translation, a predefined one-sided and biased approach is clearly not the most profitable alternative course of action. Cultural studies, however, may offer an alternative to bland detachment or partisan activism when it, in concert with gender studies, holds that gender is neither a natural nor fixed identification category. Gender is not primarily derivative from biological differences but is:

a culturally constructed script, role, or set of regulatory practices that helps to identify a given society's hegemonic norms about material bodies. Examining gender in cultures then exposes the submerged histories of those who do not fit such norms. (Smith 2012:n.p.)

A focus on gender concerns informed by cultural studies is wary of identity politics, whilst appreciative of the gains and importance of feminist work. But a broader and nonbinary optic may fit better with the constructed nature, the performativity of gender. Of the many mechanisms operative in the discourse of gender the particular influence of biblical texts in many parts of the world should not be overlooked. The intersection of cultural and gender studies allows for an ideology-adept approach to translating biblical texts.

\section{Translating New Testament gender identities and roles: The gender colour chart}

Gender is constructed in New Testament translations, that is figured or scripted but potentially in a conniving or disingenuous way, and done deliberately or inadvertently - thus (con)structed or (con)figured. ${ }^{20}$ Since gender is performativity (Butler 1990), it is scripted according to norms of the societies in which translators live, (con)figuring gender

19.And, "the laden phrase "identity politics" has come to signify a wide range of political activity and theorizing founded in the shared experiences of injustice of members of certain social groups. Rather than organizing solely around belief systems, programmatic manifestos, or party affiliation, identity political formations typically aim to secure the political freedom of a specific constituency marginalized within its larger context. Members of that constituency assert or reclaim ways of understanding their distinctiveness that challenge dominant oppressive characterizations, with the goal of greater self-determination' (Heyes 2012).

20.Along similar lines, Bailey and Pippin's (1996:1-2) promote the corrupting of translation in the deconstruction sense of the word, 'exposing and undoing racism and classicism that have been part of Eurocentric-controlled translations'. of and for the 1st century through modern-day lenses. And unless such translated gender figurations are acknowledged as such, they are rather configurations, deceptive portrayals of gender that with reference to the 1st century mislead. Whilst self-respecting academics do not view translations as innocent representations of some original truth, various culturally ordered social arrangements are at times left unaccounted for. Social conventions - and here our focus is on those regarding gender - both ancient and modern, impact in numerous but often neither in visible nor acknowledged ways on translation work. ${ }^{21}$ This impact can generate a double bind. On the one hand, attempts to make gender more visible in translated biblical texts (e.g. inclusive language; cf. Nord 2003:110-111) generally only reinforce current conventions and render past gender patterns virtually undetectable in translations. On the other hand, acknowledgement of the effect of past gender constructions on biblical texts as much as the impact of reception history with its earlier and current gender conventions, cannot always be accommodated in Bible translations. In this way, a safe course is frequently plotted in assuming a sort of neutral translation, or defaulting to - still the darling of theologians - a (so-called) 'literal' translation. ${ }^{22}$ Both the attempts to make gender constructions visible and, ironically, also those endeavours to acknowledge their impact on Bible texts and translations ensure that the double bind stays firmly in place. ${ }^{23} \mathrm{~A}$ longer example demonstrates a broader trend.

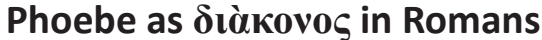

Gendered assumptions and their effects are evident in translations of Romans where Paul introduced Phoebe, one of ten other women in the chapter, as $\tau \grave{\eta} v \dot{\boldsymbol{\alpha}} \boldsymbol{\delta} \boldsymbol{\varepsilon} \boldsymbol{\lambda} \boldsymbol{\lambda} \boldsymbol{\eta} \boldsymbol{\nu} \dot{\eta} \mu \tilde{\omega} v$,

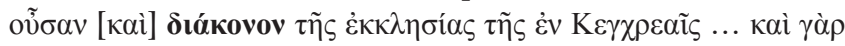

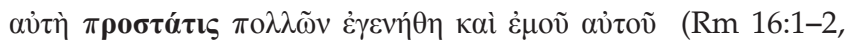
emphasis added). Phoebe's role is couched in terms that Paul used also for male counterparts and trusted co-workers such as Timothy (cf. 1 Tm 3:2). However, when Phoebe is

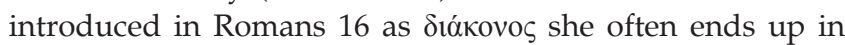
translations as 'deacon' or even - over against the Greek male form - as 'deaconess' ${ }^{24}$ (see Castelli 1999:224-225; Whelan 1993:67-85). Translating with deacon or deaconess

21.It was for example suggested that the combination of rhetorical emphasis and feminist theory will enable the 'full-turn' of biblical studies. But a paradigm shift in biblical studies has so far stayed out due to the inability of rhetoric to link up with feminist, liberationist and postcolonial studies (Schüssler Fiorenza 1999:13).

22.The remark by Aichele (2001:70) is appropriate: 'Even the most literal of translations inevitably changes the signifiers of the source texts in many ways'. And theologians
all too often use 'literal translation' as neutral, middle-of-the-road option in which the message of the text is evident, which is in any case not as Aichele (2001:74) the message of the text is evident, which is in any case not as Aichele (2001:74) text, not in order to receive a message that is contained there, but rather to text, not in order to receive a message that is contained there, but rather
uncover the "primal elements" in which pure language [a la Benjamin] rustles'.

23.The role of a gender chart in determining translation decisions has the effect of potentially blinding translators to patriarchal and heteronormative positions encapsulated in the reception history of the Bible, whilst at the same time reinforcing such positions. Here the tricky issue of inclusive language in translations of ancient texts also needs further attention.

24.The masculine form of the noun should not be taken to indicate a masculine identity imposed on Phoebe, but rather using an established term for a particular woman. Translating 'deacon' changes Phoebe 'from a leader and minister to the churches of Con 'd eacon' churches of Cenchrae into a second-level functionary', and begs the question why She would have been entrusted with this letter (Castelli 1999:224). MacDonald (1999:207), however, rates the diaconate as rather important within the early Christian church, and sees the participation of women in it as development leading to it being gendered female, including the coining of a female terms, deaconess. She does admit that this is a later development of the 3rd and 4th centuries (see also Whelan 1993:68). 
in Romans 16:1 goes against the scope of use of Stókovos in the New Testament, and is probably indicative of gender bias and (con)figuration more than anything else. ${ }^{25}$

The range of meanings for diókovo broad and includes 'assistant', 'servant', 'helper', 'attendant', or 'agent'. The lemma has a varied prevalence in different parts of speech in the New Testament; except for Philemon

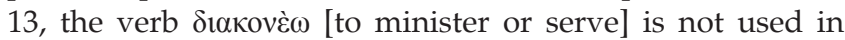
any of the other authentic Pauline letters. ${ }^{26}$ It is especially the personal noun, the term Siòkovos, that is important here, and particularly its rendering in different translations. Both

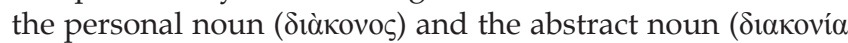
[service or ministry]), however, are used with greater frequency in the Pauline letters, respectively 12 and 18 times. ${ }^{27}$ Paul often applied the term to himself and his co-workers, particularly where the preaching of the gospel was central, for example, 1 Corinthians 3:5; 2 Corinthians 3:6; 11:23; cf. Romans 11:13; 1 Corinthians 16:15; 2 Corinthians 5:18; 6:3 (MacDonald 1999:208). In Philippians 1:1 where Paul used

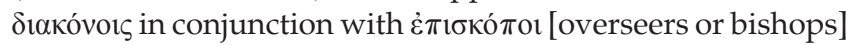
it is more likely that he indicated general terms, 'helpers' or 'assistants' or 'co-workers' as well as 'overseers' rather than instances of official roles such as 'deacons' and 'bishops' ${ }^{28}$ When Paul lists 'officers' of the church in 1 Corinthians 12:28 (cf. Eph 4:11) he only mentioned apostles, prophets, teachers, evangelists but made no mention of 'overseers' or 'deacons' (Hawthorne 2004:8-9).

In the later parts of the New Testament diókovo is used as a technical term in a few instances. Before Siókovo $\varsigma$ acquired a more technical meaning, that of an official position in church leadership ('deacon') as may be the case in rare instances such as in 1 Timothy 3:8 and 12, it was used in the New Testament with both sacred and secular connotations. Epaphras who was associated with the church in Colossae and called a diókovo $\varsigma$ in Colossians 1:7, is correctly indicated in contemporary translations not as a deacon but as 'minister' (e.g. ESV, RSV, NIV, NRSV). ${ }^{29}$ Similarly, when 1 Timothy 4:6 still later refers to Timothy, associated with the Ephesus

25.A more blatant example is of course where 'malestream' (cf. Schüssler Fiorenza 1999:49-50) interpretation turned the name of Junia into a masculine version, Junias, regardless of the fact that the latter name never appears in contemporaneous writings (Castelli 1999:225). Ascribing the change of Junia to a masculine version of the transcription of the Greek accusative (Myers 1992:829), simply begs the question why transcription is deemed appropriate only here and not with any of the other names mentioned in Romans 16. Cf. also Du Toit (1997:509-510).

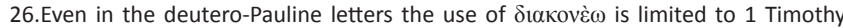
$3: 10,13$.

27.The texts are respectively Romans 13:4 [2], 15:8, 16:1; 1 Corinthians 3:5; 2 Corinthians $3: 6 ; 6: 4 ; 11: 15$ [2], 25; Galatians 2:17; Philippians $1: 1$, and Romans Corinthians 3:6; 6:4; $11: 15$ [2], 25; Galatians 2.17; Philippians $1: 1$, and Romans $4: 1 ; 5: 18 ; 6: 3,8: 4 ; 9: 1,12,13 ; 11: 8$ ). At a statistical level, the words are better represented amongst the Pauline letters than the New Testament taken as a whole represented amongst the Pauline letters than the New Testament taken as a whole,
where $\delta 1$ òkovo $\varsigma$ and $\delta 1 \alpha \kappa o v i \alpha$ are used a total of 29 and 34 times respectively; of where $\delta i \alpha \alpha_{K o v o} \zeta$ and $\delta 1 \alpha \kappa o v i \alpha$ are used a total of 29 and 34 times respectively; of
which 21 and 23 times in the Pauline corpus. In the Deutero-Pauline letters they which 21 and 23 times in the Pauline corpus. In the Deutero-Pauline letters they
are used 9 times (Eph 3:7; 6:21; Col 1:7, 23, 25; 4:7; $1 \mathrm{Tm} \mathrm{3:8,12;4:6)} \mathrm{and} 5$ (Eph $4: 12$; Col 4:17; $2 \operatorname{Tm~1:12,~4:5,~11)~times~respectively.~}$

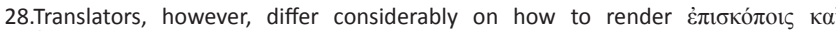

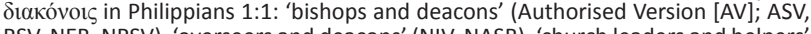
RSV, NEB, NRSV), 'overseers and deacons' (NIV, NASB), 'church leaders and helpers' (GNB), 'overseers and assistants' (Williams), 'ministers of the Church and their assistants' (Weymouth), 'superintendents and assistants' (Goodspeed), 'overseers and ministers' (Darby), or 'presidents and assistant officers' (TCNT)' (Hawthorne 2004:12).

29. English Standard Version (ESV); Revised Standard Version (RSV); New International Version (NIV); New Revised Standard Version (NRSV); Good News Bible (GNB); American Standard Version (ASV); New English Bible (NEB); New American Standard Bible (NASB); Twentieth Century New Testament (TCNT).

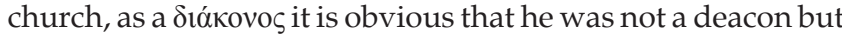
a 'minister' (RSV, NIV) or 'servant' (ESV, NRSV). In Matthew 20:26-28 Jesus is reported as using the term to describe those who followed in his footsteps and in John 12:26 to describe the relationship between him and his followers. Similarly in

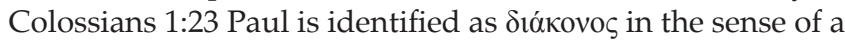
messenger of the gospel about Jesus Christ. The term was not reserved for positive descriptions only. Earlier, in Romans 13:4, Paul himself referred to state authorities, switching

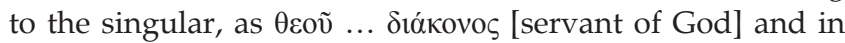

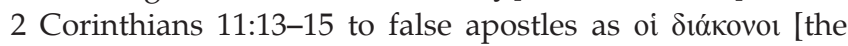
servants] of Satan.

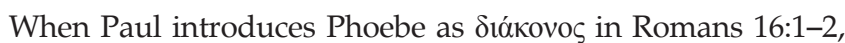
her role is best translated as a minister or co-worker of Paul and not as deacon or deaconess as borne out by her further

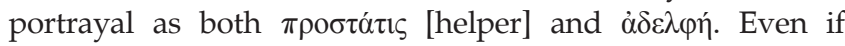
the debate on clergy chronology remains open, ascribing a

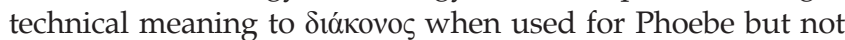
when used for others such as Timothy, is due probably more to gender construction and ideology than church organisation.

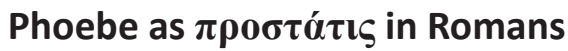

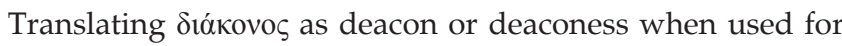
Phoebe in Romans 16 it does not take the use of the word in the New Testament into consideration, does not consider the more common meaning of the word, and appears to rely on a stance dating back to later developments when the exclusion of women from positions of leadership in the early Jesus follower communities apparently was promoted. The importance of translating diókovo $\zeta$ with a term such as minister or servant is highlighted by the social status of Phoebe expressed in $\pi \rho 0 \sigma \tau \alpha \dot{\tau} \iota \varsigma^{30}$ The loaded term $\pi \rho \circ \sigma \tau \alpha ́ \tau 1 \zeta$ is often rendered as 'helper' in translations with seeming disregard for 1st century patronage systems (Castelli 1999:224-225),

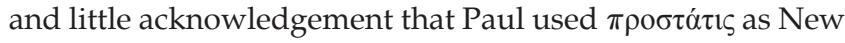
Testament hapax legomenon for Phoebe only.

In the 1st century, patronage informed social structures more than most other socio-political systems with the emperor as the supreme patron of the Roman Empire, with direct access to the gods. ${ }^{31}$ Closeness to the emperor ensured social power, and officials and local elites were able to act as brokers and clients of the emperor. Social relations were governed in a sophisticated reciprocal relationship ${ }^{32}$ where honour, prestige and power dynamics governed behaviour. ${ }^{33}$ Patronage

30.Paul used the feminine form of $\pi$ pootótms, which hints at her financial support of the Jesus follower communities, which would have implied significant economic the Jesus follower communities, which would have in
means and social independence (cf. Castelli 1999:224).

31.The importance of family metaphors in Roman society, and the father and son metaphor in particular, has also been ascribed to the portrayal of the emperor as pater patriae [Father of the Fatherland]. (Cf. e.g. Carter 2008:235-255; Lassen 1997:103-120; White 1999:139-172). For the relation between the Empire's notion of order and family relations, cf. Johnson (2007:161-73).

32. Reciprocity in patronal relations is often depicted as 'generalised' (interest of others as primary), 'balanced' (mutual interests as important) or 'negative' (dominant self-interest) (cf. Osiek 2009:144).

33.The effect of patronage was particularly evident in the relationship between freed persons and their former masters, often compared to as the relationship between son and father. The patron retained power over the freed person who was reminded of owing his or her 'new life' to the patron. Honouring of the patron was expected, and practices such as legal recourse in court for injustice suffered by the freed person, forbidden. A freed person was under the power of the patron, just as the son was under the power of the father. This unequal power relationship was managed was under the power of the father. This unequal power relationship was managed
through legislation in conjunction with honour and shame values and manifested the practical outworking of a dyadic contract, beyond manumission (cf. Chow 1997:121). 
was often covered in a 'kinship glaze' so as to soften the harshness of the client's position. Folded into fatherliness or siblinghood, and even more often, friendship terminology $y^{34}$ (Osiek 2009:144), kinship language did not hide the uneven power relationships which ruled out equality in the sense of equity or even mutuality (Punt 2012)..$^{35}$

Paul's identification of Phoebe both as minister and as patron undergirds her respected position and bestows on her a coveted social status, a public role of patronage, protection and authority, all of which would have been acknowledged publicly: 'Phoebe's role crossed the divide between public and private in Greco-Roman society' (MacDonald 1999:209). According to Paul she became ( $\dot{\varepsilon} \gamma \varepsilon v \eta \dot{\theta \eta})$ the patron of many

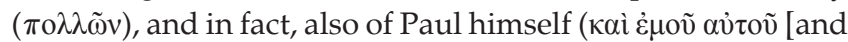
of myself]), which suggests a strong bond between her and Paul, which did not necessarily privilege Paul. Describing Phoebe as patron also fits well in with how Paul invoked fictive kinship in his communities, and his reference to her as sister.

\section{Phoebe as $\dot{\alpha} \delta \varepsilon \lambda \varphi \eta ́$ in Romans}

References to brothers and sisters in Paul's letters can simply imply membership as co-believers in Jesus, but they sometimes indicate a wider semantic reach. In 1 Corinthians 7 the differentiated use of the general $\alpha v \theta \rho \omega \pi \circ \varsigma$ [person] (e.g. 1 Cor 7:1) and particular $\alpha \delta \varepsilon \lambda \varphi$ ó [brother] (e.g. 1 Cor $7: 12)$ is a good example of the latter which was reserved for a fellow believer in Christ but also illustrates the varied use of sibling terms. Whilst Paul used similar terminology to distinguish between a fellow believer ( $\left.\dot{\alpha} \delta \varepsilon \lambda \varphi \rho^{\prime} \varsigma\right)$ and his non-

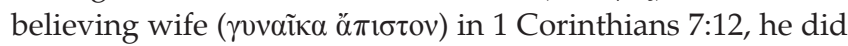
not use cognate terms to make a similar contrast between a

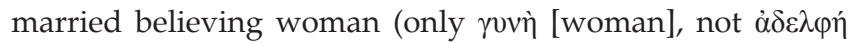

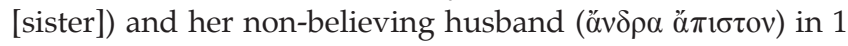
Corinthias 7:13. Although describing a parallel situation, a siblinghood term is used for the man only, not for the woman - in contrast to 1 Corinthians 7:15 where both $\alpha \delta \varepsilon \lambda \varphi$ ó $\varsigma$ and $\dot{\alpha} \delta \varepsilon \lambda \varphi \eta$ are used. Such inconsistent usage begs interpretive and translation caution.

In Romans 16:1 Phoebe is in the first place introduced as

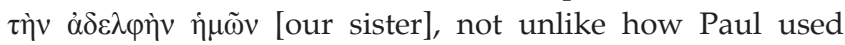
sibling terminology in communities of Jesus followers. But in Romans 16:1 he used the sibling term in neither a collective nor a generic sense. Paul did not often use the title for individuals, and there is little doubt that great respect was garnered by its use, particularly in conjunction with

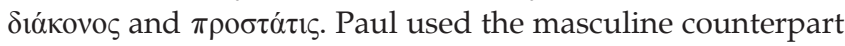
$\dot{\alpha} \delta \varepsilon \lambda \varphi$ ó $\varsigma$ for Timothy who was probably the most important collaborator in his mission (cf. Phlm 1; 2 Cor 1:1; 1 Th 3:2). Paul's identification of Phoebe as sister measures up with her

34.Other elements of patronage can be summarised as follows: asymmetrical relationships; simultaneous exchange of resources; interpersonal obligations; relational favouritism; reciprocity; exchange of honour; and, the 'kinship glaze' (Osiek 2009:144; cf. Neyrey 2005:467-468).

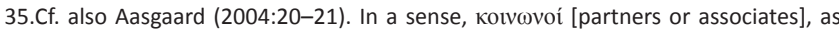

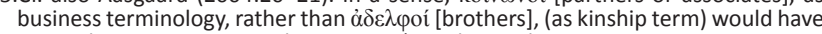
come closer to notions such as equity (equality in the contemporary context was not a socio-cultural possibility). otherwise positive description, as her assessment is on par with those of his closest associates. ${ }^{36}$ Phoebe's description fits in with the fact that she is one of three women introduced without reference to a specific partner. Some of the nine other women mentioned in Romans 16 were involved in missionary partnerships, including women (Tryphaena and Tryphosa, 16:12), male-female pairs (e.g. Prisca and Aquila, 16:3), and Rufus and his mother (16:13). But Phoebe, and maybe Mary and Persis $(16: 6,12)$, are mentioned individually, with no missionary partner.

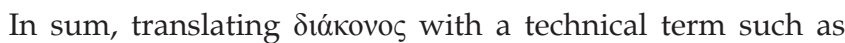
deacon or deaconess and $\pi \rho 0 \sigma \tau$ ó $\tau 1 s$ with a general notion of helper are not helpful and rest heavily upon gender constructions, or better, are gendered constructions. In the first instance these translations relegate the importance of Phoebe's role by attaching a restricted scope to it in the one case, and in the other a too casual connotation of assistance which greatly diminishes what was an important sociocultural position and role. Translation choices about Phoebe

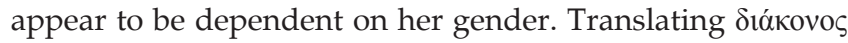
incongruously as technical term and $\pi \rho 0 \sigma \tau \dot{\alpha} \tau \iota \varsigma$ equally inappropriately as generalisation has a wider negative impact, affecting the translation of the remaining part of the text. (Con)figuring gender in translation also warps the socio-historical image of the community, as is the case in (con)figured sexuality - as another example shows.

\section{Broadening the agenda: (Con)figuring sex and sexuality}

In the Anchor Yale Bible dictionary (ABD), Myers (1992) selfconfidently writes that:

Rom 1:27 is the clearest statement in the NT regarding the issue of homosexual behavior between consenting adult males, and Rom 1:26 is the only biblical text that addresses the particular issue of homosexual behavior between consenting females. (p. 827) $)^{37}$

Myers rightly concludes that Paul's theological argument puts 'homosexuality' as consequence of sin rather than its cause or embodiment, and also that this augurs against singling out 'homosexuality' in Romans $1 .{ }^{38}$ However, choosing the modern term 'homosexuality' to express homoerotic actions and relations in antiquity, demonstrates a hermeneutical

36.Only in one other instance, Apphia in Philemon 2, did Paul identify an individual woman as $\dot{\alpha} \delta \varepsilon \lambda \varphi \eta ́$ in terms of fictive kinship. In the reference to the sister of Nereus (Rm 16:5) it is not clear whether Nereus's sibling or his missionary companion should be inferred. The 1 Timothy 5:2 exhortation $\pi \alpha \rho \alpha \kappa \alpha \dot{\lambda} \varepsilon \varepsilon 1$...

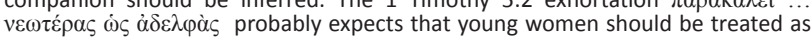
$v \varepsilon \omega \tau \varepsilon \rho \alpha \zeta \omega \zeta \alpha \delta \varepsilon \lambda \varphi \alpha \varsigma$ probably expects that young women should be treated as
siblings or sisters - as much as older men and older women should be treated as siblings or sisters - as much as older men and
father and mothers respectively (1 $\mathrm{Tm} 5: 1-2)$.

37.Myers (1992:827) also claims: 'Apparently, homosexual behavior among consenting males was quite rare amongst Israelites' and 'although homosexual love (usually in the form of pederasty, the love of an older man for a younger) enjoyed a relatively prominent place in ancient Greek social life beginning in the 6 th century $\mathrm{BC}$, homosexuality was viewed differently in the world of the 1 st century AD. To be sure, it was still practiced among some segments of society, but moral philosophers were beginning to question its merit. Homosexuality was viewed as grossly self-indulgent, essentially exploitative, and an expression of absolutely insatiable lust'.

38. A bolder position is taken by Townsley, who claims that 'there is little reason to believe that Paul's intent in this passage is anything but an exhortation against the worship of other gods, and even less basis to infer the general content of Paul's beliefs about sexual orientations, specifically the use of this passage as a condemnation of contemporary queer relationships' (Townsley 2011:728). 
bind similar to the translation of terms with which Pauline woman co-workers are described: ${ }^{39}$ How to translate without obliterating a socio-culturally different informed notion of same-sex intercourse, or without banalising or obscuring the source texts? ${ }^{40}$

Terminology used to refer to same-sex relations in the New Testament, in the three texts often cited in this regard, pose a particular challenge for Bible translation. ${ }^{41}$ The challenge is impacted by a dissimilar socio-historical context, by the often less than clear language of the New Testament, and also by contemporary debates regarding human sexuality. The stakes are raised further if one admits that Romans 1 does not deal with modern categories such as homosexual orientation; that at the time sexuality was not conceptualised along the lines modern people $\mathrm{do}^{42}$ that sex was described most often as a medium of power in the 1st century $\mathrm{CE}_{\text {; }}$ and, that homoerotic, like other sexual activities, took place in relationships characterised by inequalities of power. ${ }^{43}$ In addition, the translation of terms often connected to and translated as 'homosexual' or 'homosexuality' is further impacted upon when cognisance is given to modern-day debates on essentialism versus constructivism, when moving from identity politics bias towards a bipolar gender system to where gender is subverted, and even in some quarters already experienced as subverted - issues central (also) in cultural studies.

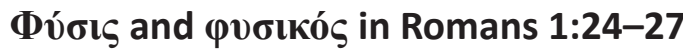

Embedded in Romans 1:21-28 (32) or more properly Romans 1:1-3:20, is Paul's strong argument of Romans 1:24-27. In these verses Paul uses homoeroticism as an example of what happens when God is not duly acknowledged. As part of his reasoning, homoerotic activities are portrayed as unnatural and participants as consumed by uncontrollable passion. ${ }^{44}$

A widespread 1st century assumption held that men could have moderate or passionless sex with women, but that male homoerotic sex was akin to passions out of control

39.For homoerotic compare especially Nissinen (1998). Also to avoid illegitimately transferring modern connotations onto ancient texts which shows no evidence of a modern sexuality binary of homosexuality and heterosexuality, Townsley (2011) uses heterogenital and homogenital.

40.For more detailed arguments, cf. earlier work done on Romans 1 in Punt (2007:965-982, 2008:73-92).

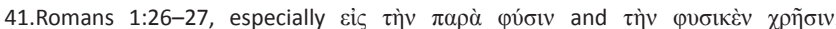

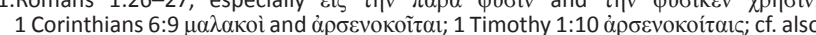
my earlier arguments in Punt (2008).

42.Balch (2003:266-268) briefly surveys a wide spectrum of 1st century CE GrecoRoman medical (Epicurus, Celsus, Soranus and Galen) and theological and philosophical (including ascetics like the Therapeutae, Philo, Chaeremon) opinion about 'sexuality' and appropriate sexual behaviour. A general uneasiness with sex is palpable, given the possibility that men might succumb to sex rather than exercising power over it in their relations with women and subordinates.

43. Biblical discussions of homoerotic activity cannot simplistically be 'cut and pasted' into today's debate; regardless of the Bible's status as authoritative text it does not directly address the issues involved (cf. Elliott 1994:181-230). Moreover, the consistent goal of early Christian ethics was the 'limitation of desire for things, experiences, and pleasures, "thou shall not desire"' (Stowers 2003:546).

44. Homoerotic activities were typically aligned in the 1st century with excessive passion: '[T] he ancient moralist, and here we must include Paul, considered homosexual behaviour to be the most extreme expression of heterosexual lust' (Martin 1995:342) and associated dangers. ${ }^{45}$ Although the example may have been extended to homoerotic activities between women (Rm 1:26), ${ }^{46}$ the passionate nature of male homoeroticism (Rm 1:27) required a longer explanation (Martin 1995:343-347; Stowers 2003:544). Probably influenced by Stoicism, Paul's argument in Romans 1 is biased towards self-mastery, implying constancy based on acting in a way that appears reasonable (Stowers 2003:529). Passion and not the modernday homosexual-heterosexual binary was a great challenge for most 1st century philosophers in the Greco-Roman world, partly because passion always threatened reason and selfmastery, but also because uncontrollable passion was equated with disaster. ${ }^{47}$ Whilst his contemporaries emphasised moderation of passion and desire and even affirmed their importance for procreative copulation, Paul is never positive about passion or desire ${ }^{48}$ (Martin 1995:347; cf. Swancutt 2003:197-205). Much emphasis is put on impassioned bodily

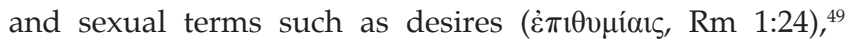

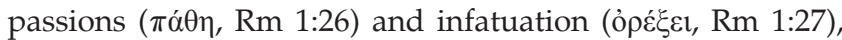
and being inflamed ( $\dot{\varepsilon} \xi \varepsilon \kappa \alpha v \dot{\theta \eta \sigma \alpha v, ~ R m ~ 1: 27): ~ ' v e r s e s ~ 24-27 ~}$ scream this language of passion' (Swancutt 2004:62). ${ }^{50}$ Paul's disquiet about desire as such - neither a distinction between homosexual and heterosexual desire nor privileging heterosexual desire - is at issue in Romans 1.

Paul shared with his contemporaries a concern for 'natural use' of sex. Natural sex partly entailed measures to ensure that passions are kept in check and under control; unnatural did not imply 'disoriented desire' but 'inordinate desire' (Martin

45.Giving oneself over to one's passions and relishing pleasure were thought to make men soft and weak, which did not have homoerotic overtones as much as an uncontrollable desire for sex with women (Stowers 2003:544-545). Deeds of softness typically included vices caused by excess, greed or lack of self-control (Frederickson 2000:219).

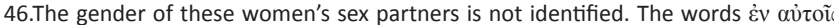
('among themselves', Rm 1:24) suggests it were people, and not for example, animals or angels (Swancutt 2004:63). But Romans 1:26 might not refer to homoerotic acts but to women who assumed a more active and hence unnatura role with men (cf. Balch 2003:277-278; Hanks 2000:90; Miller 1995:4-8, 10; also the majority of early Christian commentators on Romans, according to Martin 995:348, n. 40; Townsley 2011:708). Frederickson (2000:201) claims that he did not find any examples of the term 'use' in descriptions of homoerotic activities between women. Brooten (1996:189-302), however, believes that Romans 1:26 refers to homoerotic acts between women, which she backs up with numerous references to such acts in Greco-Roman authors: 'In sum, early Christianity was born into a world in which people from various walks of life acknowledged that women could have sexual contact with other women' (Brooten 1996:190).

47.Paul's harsh words of pronouncing divine judgement on idolatry, rest on the assumption of maintaining proper social structures, and the failure of which will mean disorder. 'In failing to respect the proper boundaries, they themselves fall into disarray' (Berger 2003:146).

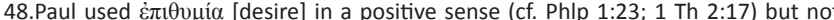
in a sexual context (Martin 1995:347). Platonist and Stoic thinking went further and prescibed $\alpha \dot{\alpha} \alpha \dot{\theta} \theta \varepsilon 1 \alpha$ [passionlessness or restraint], or 'freedom from emotions' according to Liddell, Scott and Jones (1983:174). Paul did combine 'use' with 'natural' in describing the curtailing (or even absence) of passion, as one of the 'natural' in describing the curtailing (or even absence) of passion, as one of the
three forms of 'natural' sex: procreative sex, sex preserving male superiority and three forms of 'natural' sex: procreative sex, sex prese
sex devoid of passion (Fredrickson 2000:205-206).

49.The plural may indicate a deviation from the Stoic notion of desire as root cause of the human predicament, but rather the biblical notions of desires and passions, that is, 'the complex and devious crosscurrents of human motivation involving the entire person' (Jewett 2000:225)

50.Cf. Swancutt (2003:202) on the danger of overindulgence in sex. Bodily vices are altogether absent from the long vice list in Romans 1:29-31, in contrast to antisocial behaviour (Jewett 2000:226). The list focuses on social rather than individual vices. behaviour (Jewett 2000.226). The list focuses on social rather than individual vices. The first item in the vice list $(\alpha \delta 1 \kappa i \alpha, R m 1: 29)$ injustice - a relational concept confirms the recognised paradigm of social, relational vices in the ancient ethica tradition (Engberg-Pedersen 2000:211; cf. Swancutt2004:66). Individual and socia vices were seen connected by what philosophers saw as the underlying motif of social vices: self-directedness, or the individual's concerns for his or her own body, to the exclusion of others. 
1995:342) ${ }^{51}$ In Paul's argument in Romans 1 homoeroticism becomes the example of corruption wrought by desire. Homoeroticism represented excess and loss of control and subverted the conventional male-female hierarchy rather than representing a different form of desire (cf. Martin 1995:348). In Paul's thinking, sex was primarily troublesome where it could no longer be controlled, or when it was not regulated and limited by satisfaction (Engberg-Pedersen 2000:210-211).

Natural was defined in the 1st century not by reference to a scientific-biological model typical of the 21st century. 'Unnatural' referred to unconventional practices, actions out of the ordinary or contrary to accepted social practices. ${ }^{52}$

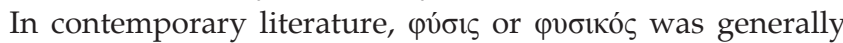
used for two categories of meaning: origin or constitution, and secondly, in medical-technical and vulgar language with reference to the genitals (Punt 2008). The reference to genitals is not picked up by the translation 'natural relations' 53 ( $\tau$ ๆेv

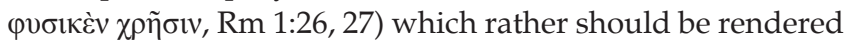
as 'natural uses or acts', that is, acts that are in accordance with the social hierarchy of society, the conventional way of acting. ${ }^{54}$ Paul's use of 'unnatural' with reference to actions is borne out also by his reference to desire (Martin 1995:341).

$[\chi] \rho \tilde{\sigma} \sigma \varsigma \varsigma$ does not refer to a relation carried out in the medium of sexual pleasure but the activity of the desiring subject, usually male, performed on the desired object, female or male (Frederickson 2000:199). ${ }^{55}$

To translate 'contrary to nature' as though Romans's reference is to the wrong object choice will be anachronistic (Martin 1995:332-355).

Finally, the general appeal to pv́бı [nature] as decisive argument is not helpful. In other instances where Paul used the same rationale in his argument (e.g. 1 Cor 11:13-15, regarding hairstyles; Rm 11:17-24 esp. 24, on the unnaturalness of the inclusion of Gentiles amongst believers), biblical interpreters generally agree on its contextually determined nature and

51.Martin (1995:293, n. 56) argues that it was a minority of Greco-Roman authors who contemplated the complete absence of desire in marriage. Frederickson (2000) puts more emphasis on the ancients' concern to control desire.

52.Nature in the 1st century and in the 20th century presupposes different cultural assumptions, world views and symbolic universes (Szesnat 1995:40). Invoking the notion of 'divine creation' to conclude towards a supra-cultural design of God in Pauline thought (cf. Wright 1993:413) is untenable at least since Paul's argument is perched on Hellenistic Jewish thought and custom where homoerotic activity was not tolerated, within a Greco-Roman world with varying opinions amidst an apparent decreasing prevalence of homoeroticsm.

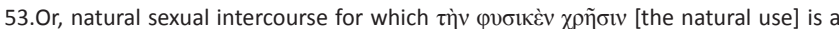
euphemism (cf. also Szesnat 1995:39, n. 8). The expression in the singular is mostly translated in the plural.

54.The nature argument heard so often in the New Testament rested on a gendered cosmology, which in terms of sexually prescribed active and passive roles, determining roles regarding penetration and, conversely, the particular penetration role determined gender (Punt 2006). With reference to today Countryman (1999:522) argues, ' $[t]$ o deny an entire class of human beings the right peaceably and without harming others to pursue the kind of sexuality that corresponds to their nature is a perversion of the gospel'.

55.The gender of the sexual partner is hardly important as his or her social status and the sexual act have to conform to the 'social status hierarchy' of the participants.

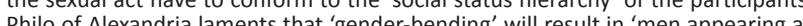
hon'

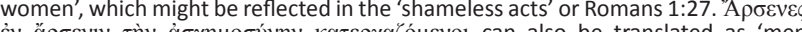

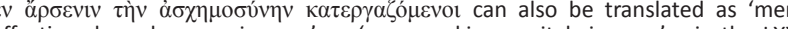
(affecting shamelessness in men", or "men working genitals in men" - in the LXX $\alpha \sigma \chi \eta \mu 0 \sigma v v \eta$ is a euphemism for genitals (e.g. Lv 18) (Szesnat 1995:39, n. 9; 43), as well as for genital nakedness and intercourse (Ex 20:26; cf. Rv 16:15) (Swancut 2004:64). relevance (Punt 2008). ${ }^{56}$ The natural use of sexual desire was often treated in the Greco-Roman world as analogous to the natural use of hunger, since both were to be limited by satisfaction: a pleasure of sex and a full stomach were of a kind $! 57$ Gluttony was unnatural not because of perverted desire but because of indulging in excess which resulted in loss of control. In short, when serving variety through such cravings, uncontrolled eating was also seen to lead to brutality and disorder (cf. Fredrickson 2000: 199ff.; Martin 1995:344, 346; Punt 2008; Swancutt 2004:62, n. 101; 2004:6465). Using words such as 'homosexuality' or 'unnatural relations' in translations of Romans 1 do not do justice to the text but rather indicates a modern worldview.

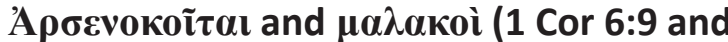 $1 \operatorname{Tm} 1: 10)$}

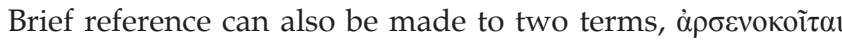
and $\mu \alpha \lambda \alpha \kappa o i ̀$ which Paul included in the vice list of 1 Corinthians 6:9-10; the first term also forms part of the list of deutero-Pauline 1 Timothy 1:10. Given their placement in these lists, both terms are used in pejorative and stereotyped rather than descriptive sense, and pose a challenge to translators. But again translations often reflect current day concerns rather than the words' entrenchment in a 1st century context. The translation of $\alpha \rho \sigma \varepsilon v о \kappa о \tilde{\tau} \alpha \boldsymbol{~ ( 1 ~ C o r ~} 6$ and $1 \mathrm{Tm} 1$ ), probably a Pauline neologism for an active male in a homoerotic context, is sometimes translated as ' behaving like a homosexual' (cf. Contemporary English Version [CEV]) or

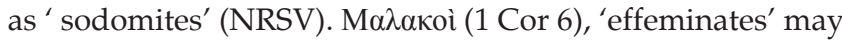
have referred to a passive male in a homoerotic context or a (male) prostitute and is often translated as '(sexual) pervert' (cf. CEV; GNB; RSV). Such translations, again, are informed by modern and heteronormative understandings of sexuality with its homosexual-heterosexual dividing line, rather than a sexual boundary that was constituted through social status and determined by activity as opposed to passivity (cf. Stegemann 1993:164)..$^{58}$

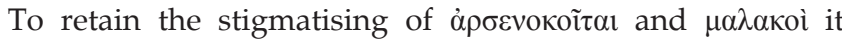
would therefore be important to translate with derisive terms - but whose derision reflects 1st and not 21st century

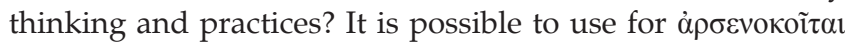

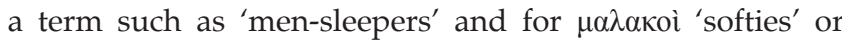
'pansies' that may carry the appropriate connotations of availability, lack of control, and susceptibility to desire. ${ }^{59}$

56.The various terms for illicit sexual activity, expressed in different ways in the New

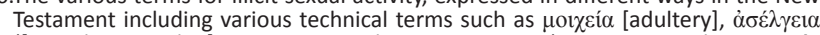
([sexual immorality], 2 Cor $2: 21 ;$ Gl 5:19; Rm 13:13) or, in particular, $\pi$ opveía [sexual immorality], do not appear in Romans 1 . However, Paul did use the word $\alpha \kappa \alpha \theta \alpha \rho \sigma i \alpha(R m 1: 24)$ to describe what he believed God delivered those who $\alpha \kappa \alpha \theta \alpha \rho \sigma i \alpha(\mathrm{Rm} 1: 24)$ to describe what he believed God delivered those who
refused to acknowledge him, into: 'uncleanness' or 'impurity'. It is a Pauline word refused to acknowledge him, into: 'uncleanness' or 'impurity'. It is a Pauline word
for impurity in settings of sexual immorality, for example, 1 Thessalonians $4: 7 ; 2$ Corinthians 12:21; Galatians 5:19; Romans 1:24; 6:19 (cf. Eph 4:19; 5:3; Col 3:5) - elsewhere in the New Testament, $\dot{\alpha} \kappa \alpha \theta \alpha \rho \sigma i \alpha$ appears only in Matthew 23:27. But impurity is used as part of the broader argument of Romans 1:18-32 which describes the results of and not the reason for of idolatry (Punt 2008).

57.At the time, sexual activity was no more but also no less dangerous than having a meal, and eating habits were as much regulated as sexual activity. The relationship between texts in the Hebrew Bible on food and those on sex, and in particular texts comparing food and sex, makes it important to consider food and sex in relation to one another (Stone 2005), also in New Testament texts.

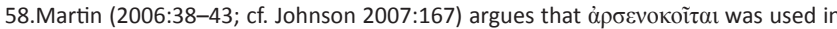
contexts reflecting economic injustice.

59.Space does not allow attention for the translations used for texts in 2 Peter and Jude regarding Sodom. 
A chauvinist approach to human sexuality complete with sanctioned male prerogative and regulated female submission ties in with a literalist appropriation of Romans 1 (cf. Davies 1995:315-332). Paul's argument that homoerotic acts are unnatural because they subvert the natural order of male-female hierarchy ${ }^{60}$ would not allow the modern reader to escape the accompanying gender ideology of the inferiority of the woman, the seducible seductress, whose dangerous sexual ability should be controlled by male sexual power (Punt 2008).

\section{Conclusion}

Cultural studies' attention to both 1st century sexual norms and practices and a long history of interpretation is neither a guarantee for proper translation, nor for addressing the latent link between misogynist and homophobic impulses, ${ }^{61}$ but provides a more responsible and accountable point of departure for translation and interpretation. Mine is not an argument for a specific translation approach as though a proper choice of theory would either eliminate or set aside cultural, ideological and other considerations, but for the awareness of cultural studies in translation theory and practice. Culture wars are fought not only in classical studies but on a broader front, with pressure also on translation work to consider its varied intersections with cultural studies. If the relationship between text and translator is as strong as expressed in the axiom that in translation we create the texts that create us (cf. Elliott \& Boer 2012:1), gender considerations in translation studies are neither inconsequential nor of mere academic interest. It is not a question whether translation work and cultural studies intersect, but rather to what degree, in which ways, to what effect and how such intersections are acknowledged and handled. ${ }^{62}$

Opting for cultural studies is not about expressing a normative claim but privileging an epistemology that engages culture seriously. One should not turn a blind eye to the cultural turn's tendency towards the balkanisation of knowledge, especially when conservative or traditional scholars withdraw to their 'bounded communities' away from the public realm. Nor should liberal scholars' uncritical engagement with popular culture be celebrated, or social location and identity be allowed to replace reason giving as the source of legitimation and delegitimation for our positions (Davaney 2001:10). ${ }^{63}$ However, acknowledgement of the intersections between cultural and translation studies allows for the required attention to be given to central concerns such as gender-appropriate translations of New Testament texts.

60.Discussions on homoerotic acts in the New Testament should consider as serious the pervasiveness of patriarchal ideology and practice at the time, as well as the serious concerns about biological productivity (Van Wijk-Bos 2003:70). 'Injustice toward the vulnerable neighbour, on the basis of human-made, time-bound, patriarchal rules, constitutes a practice of idolatry in elevating cultural norms to the status of divine commandment' (Van Wijk-Bos 2003:73)

61. Heteronormativity goes beyond 'compulsory heterosexuality' (Plaskow 2003:49ff.; cf. Loughlin 2005:24-25) and is maintained by and therefore biased towards patriarchy (cf. Punt 2008).

62. Since translations are often interfaces between competing cultural and ideological positions, the danger of bending a translation because of prevailing target norms is real (cf. Harvey 2003:43-69).

63.Another danger is obscure language: 'Too often ... the cultural turn seems to involve a linguistic turn .... towards a gestural use of language that seems designed to cloak any meaning with wispy veils of unclarity' (Louth 2007:215).

\section{Acknowledgements Competing interests}

The author declares that he has no financial or personal relationship(s) that may have inappropriately influenced him in writing this article.

\section{References}

Aasgaard, R., 2004, My beloved brothers and sisters: Christian siblingship in Paul, T \& T Clark International, London.

Aichele, G., 2001, The control of biblical meaning. Canon as semiotic mechanism, Trinity Press International, Harrisburg.

Bailey, R.C. \& Pippin, T., 1996, 'Race, class, and the politics of Bible translation: Introduction', Semeia 76, 1-6.

Balch, D.L., 2003, 'Paul, families, and households', in J.P. Sampley (ed.), Paul in the Greco-Roman world: A handbook, pp. 258-592, Trinity Press International, Harrisburg.

Berger, K., 2003, Identity and experience in the New Testament, transl. C. Muenchow, Fortress, Minneapolis.

Bernstein, R.J., 1983, Beyond objectivism and relativism: Science, hermeneutics and practice, Basil Blackwell, Oxford.

Boer, R., 2008, Last stop before Antarctica: The Bible and postcolonialism in Australia, Society of Biblical Literature, Atlanta. (Semeia Studies).

Brooten, B.J., 1996, Love between women: Early Christian responses to female homoeroticism, University of Chicago Press, Chicago/London. (Chicago Series on Sexuality, History and Society). http://dx.doi.org/10.7208/ chicago/9780226075938.001.0001

Butler, J., 1990, Gender trouble: Feminism and the subversion of identity, Routledge, New York. (Thinking Gender, 2).

Carter, W., 2008, John and empire: Initial explorations, T \& T Clark, New York/London.

Castelli, E., 1999, 'Paul on women and gender', in R.S. Kraemer \& M.R. D’Angelo (eds.) Women and Christian origins, pp. 221-235, Oxford University Press, Oxford.

Chow, J.K., 1997, 'Patronage in Roman Corinth', in R.A. Horsley (ed.), Paul and empire. Religion and power in Roman imperial society, pp. 104-125, Trinity Press International, Harrisville.

Countryman, L.W., 1999, 'New Testament sexual ethics and today's world', in K Lebacqz \& D. Sinacore-Guinn (eds.), Sexuality: A reader, pp. 515-543, Pilgrim Press, Cleveland. (Pilgrim Library of Ethics).

Culture Collective, 1995, The postmodern Bible: The Bible and culture collective, Yale University Press, New Haven.

Davaney, S.G., 2001, 'Theology and the Turn to Cultural Analysis', in D. Brown, S.G. Davaney \& K. Tanner (eds.), Converging on culture: Theologians in dialogue with cultural analysis and criticism, pp. 3-16, Oxford University Press, Oxford/New York. (AAR Reflection and Theory in the Study of Religion Series).

Davies, M., 1995, 'New Testament ethics and ours: Homosexuality and sexuality in Romans 1:26-27', Biblical Interpretation 3(3), 315-331. http://dx.doi. org $/ 10.1163 / 156851595 \times 00168$

Derrida, J., 2002, 'Des tours des Babel', in G. Anidjar (ed.), Acts of religion, pp. 102134 , Routledge, New York.

Doran, T., 2011, 'Review of Demography and the Graeco-Roman World: New insights and approaches', in C. Holleran \& A. Pudsey (eds.), Bryn Mawr classical insights and approaches', in C. Holleran \& A. Pudsey (eds.), Bryn Mawr classical
review 2012.07.49, viewed 26 November 2013, from http://bmcr.brynmawr. review 2012.07.49, viewed 2

Dube, M.W., 2001, 'What I have written, I have written, (John 19:22)?', in M.N. Getui, T.S. Maluleke \& J.S. Ukpong (eds.), Interpreting the New Testament in Africa, pp. 145-163, Acton, Nairobi.

Du Toit, A.B., 1997, 'The ecclesiastical situation of the first generation Roman Christians', HTS Teologiese Studies/Theological Studies 53(3), 498-512. http:// dx.doi.org/10.4102/hts.v53i3.1658

Easthope, A., 1994, 'Cultural studies', in M. Groden \& M. Kreiswirth (eds.), The Johns Hopkins guide to literary theory \& criticism, pp. 176-179, vol. 1, Johns Hopkins University Press, Baltimore/London.

Elliott, N., 1994, Liberating Paul: The justice of God and the politics of the Apostle, Orbis, Maryknoll. (The Bible \& Liberation, 6)

Elliott, S.S. \& Boer, R., 2012, 'Introduction', in S.S. Elliott \& R. Boer (eds.), Ideology, culture and translation, pp. 1-10, Society of Biblical Literature, Atlanta. (Semeia Studies).

Engberg-Pedersen, T., 2000, Paul and the stoics, Westminster John Knox, Louisville.

Evans, J.H., 1997, 'Worldviews or social groups as the source of moral value attributes: Implications for the culture wars thesis, Sociological Forum 12(3), 371-404.

Frederickson, D.E., 2000, 'Natural and unnatural use in Romans 1:24-27: Paul and the philosophic critique of eros', in D.L. Balch (ed.), Homosexuality, Science and the 'Plain sense' of Scripture, pp. 197-222, Eerdmans, Grand Rapids.

Free Dictionary, 2014, Identity politics, viewed 15 January 2014, from http://www. thefreedictionary.com/identity+politics

Glancy, J.A., 1998, 'House reading and field readings: The discourse of slavery and Biblical/Cultural studies', in J.C. Exum \& S.D. Moore (eds.), Biblical studies/Cultural studies: The Third Sheffield Colloquium, pp. 460-477, Sheffield Academic Press, Sheffield. (JSOTSS, 266; Gender, Culture, Theory, 7). 
Hanks, T., 2000, The subversive Gospel: A New Testament commentary on liberation, Pilgrim, Cleveland.

Harvey, K., 2003, "'Events" and "Horizons": Reading ideology in the "Bindings" of "Translations"', in M.C. Pérez (ed.), Apropos of ideology: Translation studies on ideology - Ideologies in translation studies, pp. 43-69, St Jerome, Manchester.

Hawthorne, G.F., 2004, Philippians, Word, Dallas. (Word Biblical Commentary, 43).

Heyes, C, 2012, s.v. 'Identity politics', in The Stanford encyclopedia of philosophy, Spring edn., viewed 15 January 2014, from http://plato.stanford.edu/archives/ spr2012/entries/identity-politics/

Jewett, R., 2000, 'The social context and implications of homoerotic references in Romans 1:24-27', in D.L. Balch (ed.). Homosexuality, science and the 'Plain sense' of scripture, pp. 223-241, Eerdmans, Grand Rapids.

Johnson, W.S., 2007, 'Empire and order: The Gospel and same-gender relationships, Biblical Theology Bulletin 37, 161-73. http://dx.doi.org/10.1177/014610790703 70040401

Lassen, E.M., 1997, 'The Roman family: Ideal and metaphor', in H. Moxnes (ed.), Constructing early Christian families: Family as social reality and metaphor, pp. 103-120, Routledge, London/New York.

Liddell, H.G., Scott, R. \& Jones, H.S., 1983, A Greek-English lexicon, 9th edn., Clarendon, Oxford.

Lopez, D., 2011, 'Visualizing significant otherness: Reimagining Paul(ine studies) through hybrid lenses', in D. Stanley (ed.), The colonized Apostl: Paul through postcolonial eyes, pp. 74-94, Fortress, Minneapolis. (Paul in Critical Contexts).

Loughlin, G., 2005, 'Biblical bodies', Theology \& Sexuality 12(1), 9-27. http://dx.doi. org/10.1177/1355835805057784

Louth, A., 2007, 'Review', Theology \& Sexuality 13(2), 214-215. http://dx.doi. org $/ 10.1177 / 1355835806074438$

Lundin, R., 1993, The culture of interpretation: Christian faith and the modern world, Eerdmans, Grand Rapids.

MacDonald, M.Y., 1999, 'Reading real women through the undisputed letters of Paul', in R.S. Kraemer \& M.R. D'Angelo (eds.), Women and Christian origins, pp. 199-220,Oxford University Press, Oxford.

Martin, D.B., 1995, 'Heterosexism and the interpretation of Romans 1:18-32', Biblical interpretation 3(3), 332-355. http://dx.doi.org/10.1163/156851595X00177

Martin, D.B., 2005, 'Introduction', in D.B. Martin \& P.C. Miller (eds.), The cultural turn in late ancient studies: Gender, asceticism, and historiography, pp. 1-21, Duke University Press, Durham/London. http://dx.doi.org/10.1215/9780822386681

Martin, D.B., 2006, Sex and the single savior: Gender and sexuality in biblical interpretation, Westminster John Knox, Louisville.

Miller, J.E., 1995, 'The practices of Romans 1:26: Homosexual or heterosexual?', Novum Testamentum 37(1), 1-11.http://dx.doi.org/10.1163/1568536952613631

Myers, C.D., 1992, s.v. 'Romans, epistle to the', in D.N. Freedman (ed.), The Anchor Yale Bible dictionary, Doubleday, New York, vol. 5, pp. 816-829.

Neyrey, J.H., 2005, 'God, benefactor and patron: The major cultural model for interpreting the deity in Greco-Roman antiquity', Journal for the Study of the New interpreting the deity in Greco-Roman antiquity', Journal for the Study of the
Testament 27(4), 465-492. http://dx.doi.org/10.1177/0142064X05055749

Nissinen, M., 1998, Homoeroticism in the biblical world: A historical perspective, Fortress, Minneapolis.

Nord, C., 2001, 'Dealing with purposes in intercultural communication: Some methodological considerations', Revista Alicantina de Estudios Ingleses 14, 151-166.

Nord, C., 2003, 'Function and loyalty in Bible translation', in M.C. Pérez (ed.), Apropos of ideology: Translation studies on ideology - Ideologies in translation studies, $\mathrm{pp}$. 89-112, St Jerome, Manchester.

Nord, C., 2005, Text analysis in translation. Theory, method, and didactic application of a model for translation-oriented text analysis, 2nd edn., transl. C. Nord \& P. of a model for translation-oriented text analysis, 2nd edn., transl. C. Nord \& P. Sparrow, Rodopi, Amsterd
Sprache und Literatur, 94).

Osiek, C., 2009, 'The politics of patronage and the politics of kinship: The meeting of the ways', Biblical Theology Bulletin 39(3), 143-152. http://dx.doi. of the ways', Biblical Theology
org $/ 10.1177 / 0146107909106758$

Pérez, M.C., 2003, 'Introduction', in M.C. Pérez (ed.), Apropos of ideology: Translation studies on ideology - Ideologies in translation studies, pp. 1-22, St Jerome, Manchester.

Petterson, C., 2012, 'Configuring the language to convert the people: Translating the Bible in Greenland', in S.S. Elliott \& R. Boer (eds.), Ideology, culture and translation, pp. 139-150, Society of Biblical Literature, Atlanta. (Semeia Studies).

Plaskow, J., 2003, 'Authority, resistance, and transformation: Jewish feminis reflections on good sex', in M.M. Ellison \& S. Thorson-Smith (eds.), Body and soul: Rethinking sexuality as justice-love, pp. 45-60, Pilgrim, Cleveland.

Porter, S.E., 2009, 'Assessing translation theory: Beyond literal and dynamic equivalence', in S.E. Porter \& M.J. Boda (eds.), Translating the New Testament: Text, translation, theology, pp. 117-145, Eerdmans, Grand Rapids/Cambridge. (McMaster New Testament Studies).

Punt, J., 2002, 'Translating the Bible in South Africa: Challenges to contextuality and responsibility', in A. Brenner \& J.W. van Henten (eds.), Bible translation on the threshold of the twenty-first century: Authority, reception, culture and religion, pp. 94-124, Sheffield Academic Press, Sheffield. (JSOT supplement series, vol. 313; BTC, 1).
Punt, J., 2004, 'Whose Bible, mine or yours? Contested ownership and Bible translation in southern Africa', HTS Teologiese Studies/Theological Studies 60(1/2), 307-328. $\mathrm{http}: / / \mathrm{dx}$.doi.org/10.4102/hts.v60i1/2.513

Punt, J., 2006, 'The Bible in the gay-debate in South Africa: Towards an ethics of interpretation', Scriptura 93, 419-431.

Punt, J., 2007, 'Romans 1:18-32 amidst the gay-debate: Interpretative options, HTS Teologiese Studies/Theological Studies 63(3), 965-982. http://dx.doi. org/10.4102/hts.v63i3.238

Punt, J., 2008, 'Sin as sex or sex as sin? Rom 1:18-32 as first century CE theological argument', Neotestamentica 42(1), 73-92.

Punt, J., 2012, 'He is heavy, and he's my brother. Unravelling fraternity in Paul (Galatians)', Neotestamentica 46(1), 153-171.

Pym, A., 1993, 'Review', Erudit 6(2), 184-190, viewed 09 April, from http://www. erudit.org/revue/ttr/1993/v6/n2/037160ar.pdf

Rowland, C., 1993, "'Open thy mouth for the dumb". A task for the exegete of Holy Scripture', Biblical Interpretation 1(2), 228-245. http://dx.doi. org/10.1163/156851593X00070

Schäffner, C., 2003, 'Third ways and new centres: Ideological unity or difference?', in M.C. Pérez (ed.), Apropos of Ideology: Translation studies on ideology - Ideologies in translation studies, pp. 23-41, St Jerome, Manchester.

Schüssler Fiorenza, E., 1999, Rhetoric and ethic: The politics of biblical studies, Fortress, Minneapolis.

Segovia, F.F., 2000, Decolonizing biblical studies: A view from the margins, Orbis, Maryknoll.

Segovia, F.F., 2008, 'The Bible as a text in cultures: An introduction', in C.P. deYoung, L. Guardiola-Saenz, W. Gafney, G. Tinker \& F. Yamada (eds.), The peoples' Bible, pp. 23-30, Augsburg Fortress, Minneapolis.

Smith, A., 2012, 'Cultural studies', paper presented at the SBL International Meeting, Amsterdam, 22nd-26th July.

Stanley, C.D., 2011, 'Paul the ethnic hybrid? Postcolonial perspectives on Paul's ethnic categorizations', in C.D. Stanley (ed.), The colonized Apostle: Paul through postcolonial eyes, pp. 110-126, Fortress, Minneapolis. (Paul in Critical Contexts).

Stegemann, W., 1993, 'Paul and the sexual mentality of His world', Biblical Theology Bulletin 23(4), 161-166. http://dx.doi.org/10.1177/014610799302300404

Stine, P.C. (ed.), 1992, Bible translation and the spread of the church: The last 200 years, 2nd edn., Brill, Leiden.

Stone, K., 2005, Practicing safer texts: Food, sex and Bible in queer perspective, T \& T Clark International, London/New York. (Queering Theology Series).

Stowers, S.K., 2003, 'Paul and Self-Mastery', in J.P. Sampley (ed.), Paul in the GrecoRoman World. A Handbook, pp. 524-550, Trinity Press International, Harrisburg.

Swancutt, D.M., 2003, "The disease of effemination": The charge of effeminacy and the verdict of God (Romans 1:18-2:16)', in S.D. Moore \& J.C. Anderson (eds.), New Testament masculinities, pp. 193-233, Society of Biblical Literature, Atlanta. (Semeia Studies, 45)

Swancutt, D., 2004, 'Sexy stoics and the rereading of Romans 1.18-2:16', in A. Levine \& M. Blickenstaff (eds.), A feminist companion to Paul, pp. 42-73, T\&T Clark/ Continuum, London. (Feminist companion to the New Testament and Early Christian Writings, 6)

Szesnat, H., 1995, 'In fear of androgyny: Theological reflections on masculinity and sexism, male homosexuality and homophobia, Romans 1:24-27 and Hermeneutics (A response to Alexander Venter)', Journal of Theology in Southern Africa 93, 32-50.

Thompson, J.B., 1990, Ideology and modern culture, Polity, Cambridge.

Townsley, J., 2011, 'Paul, the goddess religions, and queer sects: Romans 1:23-28', Journal of Biblical Literature 130(4), 707-728.

Van der Merwe, C.H.J. 2012, 'The Bible in Afrikaans: A direct translation - A new type of church Bible', HTS Teologiese Studies/Theological Studies 68(1), Art. \#1204, 8 pages. $\mathrm{http}: / / \mathrm{dx}$.doi.org/10.4102/hts.v68i1.1204

Vanhoozer, K.J., Anderson, C.A. \& Sleasman, M.J. (eds.), 2007, Everyday theology: How to read cultural texts and interpret trends: Cultural exegesis, Baker Academic, Grand Rapids.

Van Wijk-Bos, J.W.H., 2003, 'How to read what we read: Discerning good news about sexuality in scripture', in M.M. Ellison \& S. Thorson-Smith (eds.), Body and soul: Rethinking sexuality as justice-love, pp. 61-77, Pilgrim, Cleveland.

Werner, E., 2012, 'Toward an ethical code in Bible translation consulting', Journal of Translation 8(1), 1-8.

Whelan, C., 1993, 'Amica Pauli: The role of Phoebe in the early church', Journal for the Study of the New Testament 49, 67-85. http://dx.doi. org/10.1177/0142064X9301504905

White, J.L., 1999, The Apostle of God: Paul and the promise of Abraham, Hendrickson, Peabody.

Wright, D.F., 1993, s.v. 'Homosexuality' in G.F. Hawthorne, R.P. Martin \& D.G. Reid (eds.), Dictionary of Paul and his letters, Intervarsity Press, Downers Grove, pp. 413-415. 